\title{
SECONDARY ETIOLOGICAL FACTORS IN THE DEVELOPMENT OF PERI-IMPLANTITIS
}

\author{
Elitsa Sabeva \\ Department of Periodontology and Dental Implantology, Medical University of \\ Varna, Bulgaria.
}

\section{ABSTRACT}

Purpose: The aim of this review was to investigate the potential impact of secondary etiological factors on the development of peri-implant infections.

Results: During the review process we found sufficient evidence to define the following factors as secondary etiological factors for the development of peri-implantitis: a history of periodontitis; implant surface characteristics; suprastructure characteristics; cemented restorations; implant-abutment connection; smoking; diabetes and peri-implant mucosa characteristics.

Conclusion: To reduce the risk of peri-implantitis, the following recommendations should be considered: (1) in partially edentulous patients, implant treatment should start after elimination of the periodontal infection and after the establishment of a stable periodontal status; (2) implants should be placed in areas where there is a minimum of $2 \mathrm{~mm}$ of keratinized mucosa; (3) an internal implant-abutment connection and screw-retained suprastructures are preferred; (4) suprastructures should be planned carefully to facilitate good oral hygiene; and (5) smoking cessation should be promoted and (6) only patients with controlled diabetes should undergo implant placement.

Keywords: peri-implantitis, peri-implant mucositis, peri-implant infection,

\section{BACKGROUND}

Peri-implantitis is a biological complication of dental implant treatment that is associated with the risk of implant failure. Bacterial plaque is considered a primary etiological factor in the development of the disease. It has also been suggested that other circumstances and conditions could contribute to a higher incidence of periimplantitis. The aim of this review was to investigate the potential impacts of other factors on the development of peri-implant infections.

\section{REVIEW RESULTS}

During the review process, we found sufficient evidence to define the following factors as secondary etiological factors for the development of peri-implantitis :

\section{History of periodontitis}

Periodontal disease is considered to be one of the factors affecting marginal bone loss [1]. Many authors have suggested that a history of periodontitis is one of the potential risk factors for the development of peri-implant infections [2-8]. The prevalence of peri-implantitis is higher among patients with a history of periodontitis when compared with patients without a history of periodontitis [9]. A 2.5-fold higher risk of developing peri-implantitis was found in patients with a history of periodontitis [10]. According to different studies, peri-implantitis is associated with a similar microbiota to that observed in periodontitis [11]. Bacteria from the residual dentition could be translocated to dental implants $[12,13]$. To reduce the risk of bacterial translocation, the remaining dentition should be periodontally healthy. Factors that can enhance periodontitis, such as smoking and poor oral hygiene, could also contribute to the risk of peri-implantitis development [11]. According to other authors, a history of periodontitis and smoking has a noticeable negative effect on the success of short dental implants. The authors reported that peri-implantitis is the main reason for short implant failure [14].

Periodontal pathogens have been found in subgingival plaque in implants, even after mechanical debridement $[15,16]$. To achieve long-term success, adequate periodontal treatment must be performed before implant placement [17]. The accuracy of periodontal treatment before and after implant placement is a significant factor in maintaining the health of peri-implant tissue [6].

\section{Implant surface characteristics}

Previous studies have shown that the characteristics of the implant surface are related to the risk of developing peri-implantitis [18]. Based on comparative studies evaluating implants with comparable designs but different surface topographies, it was concluded that the mean bone loss around implants with a moderately rough and minimally rough surface is less than that around rough implants. However, due to the multifactorial etiology of bone loss, the effect of surface roughness alone on bone resorption and the risk of peri-implantitis is limited and of minimal clinical significance. In addition, there is a growing body of evidence that some factors, such as a history of periodontitis and smoking, lead to greater peri-implant bone loss [19]. According to Saulacic and Schaller, a rough surface of dental implants does not lead to a higher risk of developing peri-implantitis than that of placing implants with a machined surface [20]. Based on a retrospective study, it was concluded that the incidence of peri-implant disease is sig- 
nificantly lower in implants with a laser-microgrooved collar than that observed in implants without a lasermicrogrooved collar [21]. Mendonça et al. [22] reported a lower marginal bone loss in the lower jaw around implants with a rough collar compared to that around implants with a machined surface collar. The study was conducted around implants with an external hexagon connection. The authors did not observe a relation between the rough collar and reduced late marginal bone remodelling in the upper jaw. When comparing minimally with moderately roughened implants from clinical and microbiological points of view in patients with a history of periodontitis, no significant differences in the counts of key pathogens were found, but less bone loss was observed around minimally roughened implants after 5 years [23]. Rossi et al. [24] reported low marginal bone loss around six-millimeter implants with a moderately rough surface loaded with single crowns in the distal region for at least 10 years. According to Amoroso et al. [25], the adhesion of $P$. gingivalis to titanium is inhibited by reducing the roughness of the surface. However, it has been shown that positioning a smooth part of the implant below the level of the marginal bone can lead to its resorption [26].

\section{Suprastructure characteristics}

Prosthetic suprastructures should reduce plaque accumulation in order to minimize the risk of developing periimplantitis [17]. In a consensus report, Giovannoli et al. [27] concluded that to reduce the risk of biological complications around implants; the following recommendations should be followed: the crown margin should be located supramucosally, especially when the implants are not placed in the aesthetic area, and the prosthetic profile should favor adequate plaque control and should allow the use of instruments for interproximal oral hygiene. Poor marginal adjustment of the suprastructure and extensive gingival imitations may also be potential risk factors for the development of peri-implant infection [7]. Over-contoured prosthetic restorations are considered a critical factor in the development of peri-implantitis. Also, an emergence angle of e"30 degrees and a convex emergence profile are associated with a greater incidence of peri-implantitis [28]. Katafuchi et al. [29] came to a similar conclusion: in bone level implants, an emergence angle above 30 degrees and a convex restoration profile are risk factors for the development of periimplantitis. No significant relation has been observed between the crown/implant ratio and the prevalence of periimplantitis [28].

\section{Cemented restorations}

Subgingival cement residue seems to be related to periimplant mucositis, which could lead to the development of peri-implantitis [30]. According to Linkevicius et al. [31], it is more common for residual cement around implants to cause peri-implantitis in patients with a history of periodontitis compared with non-periodontitis patients. Excess cement in the implant-mucosal interface leads to bleeding on probing and, in some cases, to suppuration [32]. Korsch et al. [33] conducted a study aimed at comparing the effects of different luting cement on the peri-implant microflora. The authors did not find cement excess or suppuration around implants where zinc oxide eugenol cement was used. In $61 \%$ of patients in whom the suprastructures were fixed using methacrylate cement, excess material was found. Suppuration was observed in all implants with residual cement. In the methacrylate cement group, suppuration was also found in $33 \%$ of implants without excess cement. An analysis of microbial samples showed the accumulation of oral pathogens in these patients, despite the presence of excess cement. Significantly fewer oral pathogens were observed in patients in whom fixation was performed using zinc oxide eugenol cement. Another study also found a strong trend toward the bacterial invasion of methacrylate-based cement from opportunistic species and pathogens [34]. Results of a retrospective study on 71 patients with a total of 126 implants showed a remarkably large number of implants with excess methacrylate cement [32]. According to Dalago et al. [35], cemented restorations are associated with a 3.6 times higher risk of developing peri-implantitis compared with screw-retained restorations. The authors concluded that a history of periodontal disease, cemented restorations, wear crown facets, and fullmouth rehabilitation are risk factors for the development of peri-implantitis, while the characteristics of implants are not related to the disease. Screw-retained prostheses should be preferentially used to avoid complications and to reduce the risk of excess cement [27].

\section{Implant-abutment connection}

According to a previous review, there is an obvious association between the implant-abutment connection and bacterial leakage [36]. Quirynen and van Steenberghe [37] observed a significant amount of microorganisms on the apical portion of the abutment screw. As a possible cause, the authors suggested a leakage at the implant-abutment interface. In vitro and in vivo studies demonstrated that the characteristics of an implant-abutment connection influence the risk of bacterial colonization of the implant-abutment interface. Although there is a possible relation between bacterial colonization of the implant-abutment interface and crestal bone loss during the early phases of implant treatment, an evident association of initial marginal bone loss with the development of peri-implant disease was not established [38]. All types of implant-abutment connections have demonstrated a known micro-gap and bacterial micro-leakage, but conical and mixed connection systems appear to have some advantages in this regard [36]. Sanz et al. [39] concluded that implant dentistry should be focused on using customized polished abutments and an internal implantabutment connection.

According to Göthberg et al. [1], marginal bone loss is affected by the type of connection. Kim et al. [40] compared marginal bone loss in implants with an external connection and with an internal connection in the distal areas in the absence of periodontitis or peri-implantitis in adjacent teeth or implants. The authors concluded that implants with an internal connection have a more favorable bone response with respect to the marginal bone level.

Based on a literature review, Sasada and Cochran [41] reported a bone loss of 1.5 to $2.0 \mathrm{~mm}$ around bone-level implants with butt-joint connections, as the micro-gap is wide enough to allow bacterial penetration and coloniza- 
tion. In implants without an interface, such bone loss was not observed, because of the absence of a contaminated interface at the marginal bone level. Many studies have demonstrated the advantage of platform-switched implants in regard to marginal bone resorption, as they are related to a significantly different biological response. Previous publications have suggested that contamination of an implantabutment connection might have an impact on the development of peri-implantitis and on the likelihood of implant failure [41].

When studying the distribution and density of inflammatory cells around implants with supracrestal, crestal, and subcrestal locations of the implant-abutment interface, the following was observed: subcrestal interfaces were associated with a significantly higher maximum density of neutrophils around the implants than supracrestally located interfaces [42].

\section{Smoking}

Smokers who undergo dental implant treatment have a higher risk of developing peri-implantitis [43]. Smoking affects the peri-implant microflora, even in healthy patients, leading to a reduction in commensal species and an increase in pathogens. The transition from a state of health to periimplant mucositis and peri-implantitis differs in smokers, as additional enrichment of the microflora occurs [44]. Other authors have also come to a similar conclusion [45]. According to a previous study, smoking and a history of periodontitis are important risk factors for a more severe course of peri-implantitis. It was suggested the combination of these two risk factors does not further increase the severity of periimplantitis compared with the presence of each of them alone. Early diagnosis and proper treatment of periimplantitis are essential in patients with a history of periodontitis and in smokers to minimize the risk of periimplantitis [7]. Other authors have also commented on the higher incidence of peri-implantitis in patients with periodontitis and smokers [46]. Romanos et al. [47] concluded that careful selection of patients and control of systemic factors such as smoking and diabetes, combined with exact surgical and prosthetic planning, permits better prevention and infection control. Another study also commented on the impacts of smoking and diabetes, concluding that both factors are associated with the development of peri-implant infection [48]. Smoking significantly alters the salivary Gram-positive bacterial microflora, including pathogens that are potentially important in the pathogenesis of diseases such as periodontitis and peri-implantitis [49].

\section{Diabetes}

The risk of developing peri-implantitis is higher in patients with uncontrolled diabetes and cardiovascular disease [46]. According to a systematic literature review, diabetes is associated with a higher risk of developing periimplantitis, regardless of smoking status [50]. Other studies also support the opinion that diabetes influences the development of peri-implantitis $[47,48,51,52]$. According to Schwarz et al. [53], data suggesting that smoking and diabetes are potential risk factors for peri-implantitis are inconclusive. In a systematic literature review, it was concluded that patients with poorly controlled diabetes have impaired osseointegration, an increased risk of periimplantitis, and a higher rate of implant failure [54].

\section{Peri-implant mucosa characteristics}

According to a systematic literature review, the amount of keratinized mucosa around an implant has a small impact on soft tissue inflammation in the presence of adequate oral hygiene. Suboptimal oral hygiene as a result of difficult access to plaque control in areas with a minimal amount of keratinized mucosa may cause greater tissue damage. The presence of less than $2 \mathrm{~mm}$ of keratinized mucosa is associated with peri-implant discomfort during brushing as well as the development of plaque and inflammation [55]. Other authors came to the conclusion that a lack of keratinized mucosa around implants is related to plaque accumulation and soft-tissue recession, even when the patients exercise good oral hygiene and receive proper supporting periodontal therapy [56]. The presence of less than $2 \mathrm{~mm}$ of keratinized mucosa around implants in patients who do not regularly participate in maintenance is associated with periimplant disease [57]. In a study whose aim was to observe the relationship between peri-implant soft tissue biotypes and peri-implantitis severity, it was concluded that a thin biotype might be a predisposing factor for increased periimplantitis severity. Patient collaboration on maintenance therapy and the presence of periodontitis may be important indicators of the risk of peri-implantitis progression in implants in which the keratinized mucosa is thin or absent [58]. In a systematic literature review, Brito et al. [59] concluded that a sufficient amount of keratinized mucosa may be required, as it has been shown to be associated with better peri-implant tissue health. In a consensus report on the surgical treatment of peri-implantitis, it was concluded that the best approach to optimize the width of the keratinized attached mucosa and to reduce plaque and bleeding scores as well as to maintain a stable level of marginal peri-implant bone is to use an apically positioned flap combined with a free gingival graft [60]. Increased buccal soft tissue thickness was found to be associated with the lower marginal bone loss [1]. Giovannoli et al. [27] recommended the correction of soft-tissue defects and preservation of a minimum amount of non-mobile keratinized mucosa to maintain peri-implant health. According to Boynueðri et al. [61], a sufficient width of keratinized mucosa may be essential for plaque control, and plaque is associated with peri-implant mucosal lesions.

\section{CONCLUSION}

Based on this literature review, it can be concluded that certain factors could increase the risk of developing peri-implantitis. A history of periodontitis, smoking, diabetes, an inadequate amount of keratinized mucosa around dental implants, as well as the characteristics of the implantabutment connection and the suprastructure could be considered to be secondary etiological factors for the development of peri-implant infection. The data about the role of the implant surface topography are controversial. Among the above mentioned factors, a history of periodontitis and cemented suprastructures seem to have the greatest associations with the occurrence of biological complications. To 
reduce the risk of peri-implantitis, the following recommendations should be considered: (1) in partially edentulous patients; implant treatment should start after elimination of the periodontal infection and after the establishment of a stable periodontal status; (2) implants should be placed in areas where there is a minimum of $2 \mathrm{~mm}$ keratinized mu- cosa; (3) an internal implant-abutment connection and screw-retained suprastructures are preferred; (4) suprastructures should be planned carefully to facilitate good oral hygiene, and (5) smoking cessation should be promoted, and (6) only patients with controlled diabetes should undergo implant placement.

\section{REFERENCES:}

1. Göthberg C, Gröndahl K, Omar O, Thomsen P, Slotte C. Bone and soft tissue outcomes, risk factors, and complications of implant-supported prostheses: 5-Years RCT with different abutment types and loading protocols. Clin Implant Dent Relat Res. 2018 Jun;20(3):313-321. [PubMed]

2. Ferreira SD, Martins CC, Amaral SA, Vieira TR, Albuquerque BN, Cota LOM, et al. Periodontitis as a risk factor for peri-implantitis: Systematic review and meta-analysis of observational studies. J Dent. 2018 Dec;79:110. [PubMed]

3. Renvert S, Persson GR. Periodontitis as a potential risk factor for periimplantitis. J Clin Periodontol. 2009 Jul;36 Suppl 10:9-14. [PubMed]

4. Altay MA, Tozoðlu S, Yýldýrýmyan N, Özarslan MM. Is History of Periodontitis a Risk Factor for Peri-implant Disease? A Pilot Study. Int J Oral Maxillofac Implants. 2018 Jan-Feb;33(1):152-160. [PubMed]

5. Papi P, Di Murro B, Pranno N, Bisogni V, Saracino V, Letizia C, et al. Prevalence of peri-implant diseases among an Italian population of patients with metabolic syndrome: A cross-sectional study. J Periodontol. 2019 Dec;90(12):1374-1382. [PubMed]

6. Ogata Y, Nakayama Y, Tatsumi J, Kubota T, Sato S, Nishida T, et al. Prevalence and risk factors for peri-implant diseases in Japanese adult dental patients. J Oral Sci. 2017 Mar 31;59(1):1-11. [PubMed]

7. Saaby M, Karring E, Schou S, Isidor F. Factors influencing severity of peri-implantitis. Clin Oral Implants Res. 2016 Jan;27(1):7-12. [PubMed]

8. Kordbacheh Changi K, Finkelstein J, Papapanou PN. Periimplantitis prevalence, incidence rate, and risk factors: A study of electronic health records at a U.S. dental school. Clin Oral Implants Res. 2019 Apr; 30(4):306-314. [PubMed]
9. Ramanauskaite A, Baseviciene N, Wang HL, Tözüm TF. Effect of history of periodontitis on implant success: meta-analysis and systematic review. Implant Dent. 2014;23(6):687696. [PubMed]

10. Arunyanak SP, Sophon N, Tangsathian T, Supanimitkul K, Suwanwichit T, Kungsadalpipob K. The effect of factors related to periodontal status toward peri-implantitis. Clin Oral Implants Res. 2019 Aug;30(8):791-799. [PubMed]

11. Quirynen M, De Soete M, van Steenberghe D. Infectious risks for oral implants: a review of the literature. Clin Oral Implants Res. 2002 Feb;13(1):1-19. [PubMed]

12. Quirynen M, Abarca M, Van Assche N, Nevins M, van Steenberghe D. Impact of supportive periodontal therapy and implant surface roughness on implant outcome in patients with a history of periodontitis. J Clin Periodontol. 2007;34(9):805-815. [PubMed]

13. Callan DP, Cobb CM, Williams KB. DNA probe identification of bacteria colonizing internal surfaces of the implant-abutment interface: a preliminary study. J Periodontol. 2005 Jan;76(1):115-20. [PubMed]

14. Hasanoglu Erbasar GN, Hocaoðlu TP, Erbasar RC. Risk factors associated with short dental implant success: a long-term retrospective evaluation of patients followed up for up to 9 years. Braz Oral Res. 2019; 33:e030. [PubMed]

15. Nie J, Zhang Q, Zheng $\mathrm{H}, \mathrm{Xu}$ LX, Wang XY, Chen F. Pyrosequencing of the subgingival microbiome in periimplantitis after non-surgical mechanical debridement therapy. J Periodontal Res. 2020 Apr;55(2):238-246. [PubMed]

16. Wu YW, Zheng H, Li XF, Lu H, Lu SH, Liu XH, et al. Changes of Microbial Community in Treated Peri- implantitis Sites: An Experimental Study in Beagle Dogs. Chin J Dent Res. 2019; 22(3):165-173. [PubMed]

17. Ito T, Nishimura K, Ogasawara R, Furuya Y, Yajima Y. Role of Dental Implant Superstructure in Patients with Severe Periodontal Disease. Bull Tokyo Dent Coll. 2019 Jun 21;60(2):105-114. [PubMed]

18. Rakic M, Galindo-Moreno P, Monje A, Radovanovic S, Wang HL, Cochran D, et al. How frequent does peri-implantitis occur? A systematic review and meta-analysis. Clin Oral Investig. 2018 May;22(4):1805-1816. [PubMed]

19. De Bruyn H, Christiaens V, Doornewaard R, Jacobsson M, Cosyn $\mathrm{J}$, Jacquet W, et al. Implant surface roughness and patient factors on longterm peri-implant bone loss. Periodontol 2000. 2017 Feb;73(1): 218-227. [PubMed]

20. Saulacic N, Schaller B. Prevalence of Peri-Implantitis in Implants with Turned and Rough Surfaces: a Systematic Review. J Oral Maxillofac Res. 2019 Mar 31;10(1):e1. [PubMed]

21. Guarnieri R, Grande $M$, Zuffetti F, Testori T. Incidence of Periimplant Diseases on Implants With and Without Laser-Microgrooved Collar: A 5-Year Retrospective Study Carried Out in Private Practice Patients. Int J Oral Maxillofac Implants. $2018 \mathrm{Mar} /$ Apr;33(2):457-465. [PubMed]

22. Mendonca JA, Senna PM, Francischone CE, Francischone Junior CE, de Souza Picorelli Assis NM, Sotto-Maior BS. Retrospective Evaluation of the Influence of the Collar Surface Topography on Peri-implant Bone Preservation. Int $J$ Oral Maxillofac Implants. 2017 Jul-Aug; 32(4):858-863. [PubMed]

23. Raes M, D'hondt R, Teughels W, Coucke W, Quirynen M. A 5-year randomized clinical trial comparing minimally with moderately rough im- 
plants in patients with severe periodontitis. J Clin Periodontol. 2018 Jun;45(6):711-720. [PubMed]

24. Rossi F, Lang NP, Ricci E, Ferraioli L, Baldi N, Botticelli D. Long-term follow-up of single crowns supported by short, moderately rough implants-A prospective 10-year cohort study. Clin Oral Implants Res. 2018 Dec;29(12):1212-1219. [PubMed]

25. Amoroso PF, Adams RJ, Waters MG, Williams DW. Titanium surface modification and its effect on the adherence of Porphyromonas gingivalis: an in vitro study. Clin Oral Implants Res. 2006 Dec;17(6):633-7. [PubMed]

26. Schwarz F, Alcoforado G, Nelson K, Schaer A, Taylor T, Beuer F, et al. Impact of implant-abutment connection, positioning of the machined collar/microgap, and platform switching on crestal bone level changes. Camlog Foundation Consensus Report. Clin Oral Implants Res. 2014 Nov;25(11):1301-1303. [PubMed]

27. Giovannoli JL, Roccuzzo M, Albouy JP, Duffau F, Lin GH, Serino G. Local risk indicators - Consensus report of working group 2. Int Dent J. 2019 Sep;69 Suppl 2:7-11. [PubMed]

28. Yi Y, Koo KT, Schwarz F, Ben Amara H, Heo SJ. Association of prosthetic features and peri-implantitis: A cross-sectional study. J Clin Periodontol. 2020 Mar;47(3):392-403 [PubMed]

29. Katafuchi M, Weinstein BF, Leroux BG, Chen YW, Daubert DM. Restoration contour is a risk indicator for peri-implantitis: A cross-sectional radiographic analysis. J Clin Periodontol. 2018 Feb;45(2):225-232. [PubMed]

30. Quaranta A, Lim ZW, Tang J, Perrotti V, Leichter J. The Impact of Residual Subgingival Cement on Biological Complications Around Dental Implants: A Systematic Review. Implant Dent. 2017 Jun;26(3):465-474. [PubMed]

31. Linkevicius T, Puisys A, Vindasiute E, Linkeviciene L, Apse P. Does residual cement around implantsupported restorations cause peri-implant disease? A retrospective case analysis. Clin Oral Implants Res. 2013 Nov;24(11):1179-84. [PubMed]

32. Korsch M, Obst U, Walther W. Cement-associated peri-implantitis: a retrospective clinical observational study of fixed implant-supported restorations using a methacrylate cement. Clin Oral Implants Res. $2014 \mathrm{Jul}$; 25(7):797-802. [PubMed]

33. Korsch M, Marten SM, Dötsch A, Jáuregui R, Pieper DH, Obst U. Effect of dental cements on peri-implant microbial community: comparison of the microbial communities inhabiting the peri-implant tissue when using different luting cements. Clin Oral Implants Res. 2016 Dec;27(12):e161e166. [PubMed]

34. Korsch M, Walther W, Marten SM, Obst U. Microbial analysis of biofilms on cement surfaces: An investigation in cement-associated periimplantitis. J Appl Biomater Funct Mater. 2014 Sep 5;12(2):70-80. [PubMed]

35. Dalago HR, Schuldt Filho G, Rodrigues MA, Renvert S, Bianchini MA. Risk indicators for Periimplantitis. A cross-sectional study with 916 implants. Clin Oral Implants Res. 2017 Feb;28(2):144-150. [PubMed]

36. Candotto V, Gabrione F, Oberti L, Lento D, Severino M. The role of implant-abutment connection in preventing bacterial leakage: a review. $J$ Biol Regul Homeost Agents. 2019 MayJun;33(3 Suppl. 1):129-134. [PubMed]

37. Quirynen M, van Steenberghe D. Bacterial colonization of the internal part of two-stage implants. An in vivo study. Clin Oral Implants Res. 1993 Sep;4(3):158-61. [PubMed]

38. Koutouzis T. Implant-abutment connection as contributing factor to peri-implant diseases. Periodontol 2000. 2019 Oct;81(1):152-166. [PubMed]

39. Sanz M, Noguerol B, SanzSanchez I, Hammerle CHF, Schliephake H, Renouard F, et al. European Association for Osseointegration Delphi study on the trends in Implant Dentistry in Europe for the year 2030. Clin Oral Implants Res. 2019 May;30(5):476-486. [PubMed]

40. Kim DH, Kim HJ, Kim S, Koo KT, Kim TI, Seol YJ, et al. Comparison of marginal bone loss between internal- and external-connection dental implants in posterior areas without periodontal or peri-implant disease. $J$ Periodontal Implant Sci. 2018 Apr
30;48(2):103-113. [PubMed]

41. Sasada Y, Cochran DL. ImplantAbutment Connections: A Review of Biologic Consequences and Periimplantitis Implications. Int J Oral Maxillofac Implants. 2017 Nov/Dec; 32(6):1296-1307. [PubMed]

42. Broggini N, McManus LM, Hermann JS, Medina R, Schenk RK, Buser D, et al. Peri-implant inflammation defined by the implant-abutment interface. J Dent Res. 2006 May;85(5): 473-8. [PubMed]

43. Haas R, Haimböck W, Mailath G, Watzek G. The relationship of smoking on peri-implant tissue: a retrospective study. J Prosthet Dent. 1996 Dec;76(6):592-6. [PubMed]

44. Tsigarida AA, Dabdoub SM, Nagaraja HN, Kumar PS. The Influence of Smoking on the Peri-Implant Microbiome. J Dent Res. 2015 Sep; 94(9):1202-17. [PubMed]

45. Pimentel SP, Fontes M, Ribeiro FV, Corrêa MG, Nishii D, Cirano FR, et al. Smoking habit modulates periimplant microbiome: A case-control study. J Periodontal Res. 2018 Dec; 53(6):983-991. [PubMed]

46. Ting M, Craig J, Balkin BE, Suzuki JB. Peri-implantitis: A Comprehensive Overview of Systematic Reviews. J Oral Implantol. 2018 Jun; 44(3):225-247. [PubMed]

47. Romanos GE, Delgado-Ruiz R, Sculean A. Concepts for prevention of complications in implant therapy. Periodontol 2000. 2019 Oct;81(1):717. [PubMed]

48. Turri A, Rossetti PH, Canullo L, Grusovin MG, Dahlin C. Prevalence of Peri-implantitis in Medically Compromised Patients and Smokers: A Systematic Review. Int J Oral Maxillofac Implants. 2016 Jan-Feb;31(1):111-8. [PubMed]

49. Grine G, Royer A, Terrer E, Diallo OO, Drancourt M, Aboudharam G. Tobacco Smoking Affects the Salivary Gram-Positive Bacterial Population. Front Public Health. 2019 Jul 19;7:196. [PubMed]

50. Monje A, Catena A, Borgnakke WS. Association between diabetes mellitus/hyperglycaemia and peri-implant diseases: Systematic review and meta-analysis. J Clin Periodontol. 2017 Jun;44(6):636-648. [PubMed]

51. Dreyer H, Grischke J, Tiede C, 
Eberhard J, Schweitzer A, Toikkanen SE, et al. Epidemiology and risk factors of peri-implantitis: A systematic review. J Periodontal Res. 2018 Oct; 53(5):657-681. [PubMed]

52. Meza Maurício J, Miranda TS, Almeida ML, Silva HD, Figueiredo LC, Duarte PM. An umbrella review on the effects of diabetes on implant failure and peri-implant diseases. Braz Oral Res. 2019 Sep 30;33(suppl 1):e070. [PubMed]

53. Schwarz F, Derks J, Monje A, Wang HL. Peri-implantitis. J Periodontol. 2018 Jun;89 Suppl 1:S267S290. [PubMed]

54. Naujokat H, Kunzendorf B, Wiltfang J. Dental implants and diabetes mellitus-a systematic review. Int $J$ Implant Dent. 2016 Dec;2(1):5. [PubMed]

55. Pranskunas M, Poskevicius L, Juodzbalys G, Kubilius R, Jimbo R.
Influence of Peri-Implant Soft Tissue Condition and Plaque Accumulation on Peri-Implantitis: a Systematic Review. J Oral Maxillofac Res. 2016 Sep 9;7(3):e2. [PubMed]

56. Roccuzzo M, Grasso G, Dalmasso P. Keratinized mucosa around implants in partially edentulous posterior mandible: 10-year results of a prospective comparative study. Clin Oral Implants Res. 2016 Apr;27(4):491-6. [PubMed]

57. Monje A, Blasi G. Significance of keratinized mucosa/gingiva on peri-implant and adjacent periodontal conditions in erratic maintenance compliers. J Periodontol. 2019 May;90(5):445-453. [PubMed]

58. Isler SC, Uraz A, Kaymaz O, Cetiner D. An Evaluation of the Relationship Between Peri-implant Soft Tissue Biotype and the Severity of Peri-implantitis: A Cross-Sectional
Study. Int J Oral Maxillofac Implants. 2019 Jan-Feb;34(1):187-196. [PubMed]

59. Brito C, Tenenbaum HC, Wong BK, Schmitt C, Nogueira-Filho G. Is keratinized mucosa indispensable to maintain peri-implant health? A systematic review of the literature. $J$ Biomed Mater Res B Appl Biomater. 2014 Apr;102(3):643-50. [PubMed]

60. Khoury F, Keeve PL, Ramanauskaite A, Schwarz F, Koo KT, Sculean A, et al. Surgical treatment of peri-implantitis - Consensus report of working group 4. Int Dent J. 2019 Sep;69 Suppl 2:18-22. [PubMed]

61. Boynueðri D, Nemli SK, Kasko YA. Significance of keratinized mucosa around dental implants: a prospective comparative study. Clin Oral Implants Res. 2013 Aug;24(8):928-33. [PubMed]

Please cite this article as: Sabeva E. Secondary Etiological Factors in the Development of Peri-implantitis. J of IMAB. 2021 Apr-Jun;27(2):3682-3687. DOI: https://doi.org/10.5272/jimab.2021272.3682

Received: 27/05/2020; Published online: 05/04/2021

Address for correspondence:

Elitsa Sabeva

Department of Periodontology and Dental Implantology, Faculty of Dental Medicine, Medical University of Varna,

84, Tzar Osvoboditel Blvd., 9000 Varna, Bulgaria.

E-mail: elica.sabeva@mail.bg 